archives and archivists as essentially a service-but this should be expected and, within the context and purpose of the Conference, it seems proper. Nevertheless, archives are peripheral to the interests of most Conference delegates. That being the case, is participation by archives worthwhile or a waste of time? The dilemma is complete, for I left the seventeenth Conference in Fredericton in 1977 convinced that archival participation was useless, and emerged from the eighteenth Conference feeling that there was potential relevance. In fact, archivists will only get out of the Conference what they are willing to put into it. While ignoring the event would save the federal, provincial, and territorial archives some time and expense, it would also deprive them of a potentially useful forum. The archives in each jurisdiction will have to determine, in discussion with the appropriate government officials in the museum and historical sites community, the extent and nature of its participation in each future conference. My feeling is that they should promote quite active involvement and focus annual reports to the Conference on resources and facilities available for heritage research, and on problems directly related to them. Their objective should be to stimulate understanding and sympathy for archives within the historical resource community.

Jay Atherton

Public Archives of Canada.

\title{
North American Fur Trade
}

In welcoming the several hundred participants to the Third North American Fur Trade Conference in Winnipeg, 4-6 May 1978, Professor W.L. Morton suggested with gratification that their attendance was evidence that fur trade studies had not been consigned either to oblivion or to the antiquarians.

The phenomenal increase in the use of the Hudson's Bay Company archives since they were transferred from Beaver House in London to Winnipeg is sufficient testimony to support Morton's observations. The papers presented at the conference were further confirmation of his remarks, and the enthusiasm engendered-indicated in preliminary plans for a fourth conference-provided grounds for believing that fur trade studies were "alive and well".

Many of the papers presented challenged any assumption that the history of the fur trade has been completed. Arthur Ray's (York University) paper on the Indian as a consumer, containing references to complaints by Hudson's Bay Company factors regarding the poor quality of trade goods may lead eventually to some revisions of Harold Innis' history of the fur trade and of his thesis in respect to the superiority of English over French trade goods and the relationship between that supposed superiority and the fall of New France. It is always disturbing to realize that Innis, who produced a work consistently referred to as the "standard" or "classic" study on the fur trade, did his research before the Hudson's Bay Company archives were open to historians.

Readers of Hudson's Bay Company history will have noted the profuse employment of Orcadians to whom the Company appeared to be addicted. Part of the reason was provided in an imaginative and seminal paper by John Nicks (University of Alberta) who had investigated local records in the Orkney Islands and presented some conclusions on the social, family and economic conditions in the area. This paper and that of Carol Judd on the ethnicity of the Hudson's Bay Company employees in the nineteenth century serve to illustrate but one of the many new avenues of research being followed in fur trade studies.

Other avenues could be mentioned: the fur trade and the mapping of North 
America, the impact of the trade on Indian culture, the social and labour history of the fur trade. Historians appear to be playing a diminishing role in this work, the impetus in fur trade studies now being with the geographers, anthropologists, enthnolgists, conservationists. Our current interest in northern resources and native land claims has provided an incentive to look at old records with a new purpose. The opening of the post-1870 records of the Hudson's Bay Company has extended our view in such traditional areas of interest as the relationship between settlement and railway routes, and invited exploration into new areas such as the land business of the Company and the development of capital investment in the west. The beginnings of urban development in the West will have to be re-written in the light of the Company's land records.

Fur trade correspondence, journals and reports can tell us more than the story of a business activity. Sylvia Van Kirk's (University of Toronto) pioneering study of the role of women in the fur trade represents the use to which the records may be put as new approaches to a broader interpretation of history and other disciplines are undertaken. Through some of the fur trade records can be traced the territoriality of individual Indian hunters, the composition of Indian groups, and residence and kinship patterns-all of interest to the anthropologist. The Hudson's Bay Company's shipping registers, which record the British firms from whom trade goods were purchased, might inspire a researcher to undertake a study of the association between the fur trade and the growth of the British industrial and manufacturing community. The great number of Grants, Rosses, Simpsons, Hargraves', Mactavish's, and so on, in the fur trade and the tendency of sons and relatives to enter the trade suggest the possibility, perhaps for a sociologist, of a study of the Victorian family unit living in isolation from "civilized" society. The Hudson's Bay Company archives' extensive collection of employees' wills, contracts and accounts, and biographical files would be of great assistance in such a study. One project already underway based on the Company's records involves the study of deviant behaviour, personality disorders, and the effect of isolation on behaviour patterns and personality.

As the approaches to history and other disciplines change, and as new techniques within the disciplines evolve, so will the use to which fur trade records will be put. Computer technology makes manageable the statistical data in the records and will lead to studies in quantitative history. The only limit to be placed on the use of the records is the limit of the researcher's imagination. The fur trade conference indicated how that imagination has been broadened in the last few years and led participants to express a feeling of anticipation for the results of this new research at future conferences. [Editor's note: Papers of the conference will be published in 1979.]

Hartwell Bowsfield

York University

\section{International Military History Colloquy}

Representatives of twenty five countries met in Ottawa, 19-29 August 1978, for a session of the International Military History Colloquy. This gathering, held at irregular intervals and sponsored by the International Commission for Military History, took for its theme "Armed Forces and Colonial Development". Papers from a distinguished group of academics and official historians ranged in time from imperial Rome to the policing of modern Palestine and in extent across the globe. The strongest impression left by the conference is that military history, long a highly specialized and distinct area of study, is rapidly moving into the historical mainstream while at the same time intensifying its emphasis on comparative studies.

A number of contributions dealt with established considerations like strategy and 